\title{
OPTIMASI PENCARIAN KATA-KATA DALAM EMPAT KITAB HADIS
}

\author{
${ }^{1}$ Sunita Agustina, ${ }^{2}$ Dwi Sakethi, ${ }^{3}$ Rizky Prabowo, ${ }^{4}$ Rico Andrian \\ ${ }^{1}$ Jurusan Ilmu Komputer FMIPA Unila
}

\begin{abstract}
Source of Islamic law is the major reference or foundation in Islamic law decision making. There are 3 sources of Islamic law; Al-Quran, Hadith, and Ijtihad. The rise of information technology development is expected to result an optimal outcome in data search, as the information search pertaining to hadith can be more effective and easier to be applied in daily life. In the existing hadith search system, there's merely one hadith book and the search result itself is not in chronological order. The hadith search system was done by the author is the development in hadith information search optimization with calculation in every word's input with quality value of 3 for every 3 words being input, 2 for 2 words and 1 for a word. After obtaining the development of word search with one until three, shown similar words accordance with the keywords users have input beforehand. With the sequence of search result, from 3, 2 and lastly one word. The examination is done with Blackbox testing and questionnaire examination. In blackbox testing, it is proven that the system is valid enough functionally. From questionnaire examination, specifically statement examination, resulted to index value at $88,05 \%$, pointing that the respondents are agree to the given statements. From comparison examination, it is acquired that 190 respondents select the recent system, showing that the recent system has done good optimization.
\end{abstract}

Keywords: Hadith, Optimization, Words Search.

\section{Pendahuluan}

Pendidikan Islam sekarang ini belum sepenuhnya islami, hal ini diperjelas dengan banyaknya teori yang dipergunakan sebagai landasan pendidikan masih merujuk pada buatan Barat. Pendidikan Islam perlu diperkuat, diantara caranya ialah merujuk pada hadis-hadis Rasulullah Saw (hadits tarbawy) [1]. Pada perkembangan teknologi informasi seperti aplikasi pengolahan database sangat diharapkan, terutama yang berkaitan dengan pencarian suatu data. Ada beragam cara untuk memaksimalkan pencarian data seperti penelitian [2] yang berjudul Optimasi Query Untuk Pencarian Data Menggunakan Penguraian Kalimat mengimplementasikan bagaimana menghasilkan query untuk pencarian data dengan menggunakan kunci pencarian yang diurai susunannya sebagai syarat pencarian.

Pada penelitian sebelumnya yang relevan yaitu [3] penelitian sistem pencarian informasi hadits riwayat Bukhari hanya terdapat satu kitab hadis yaitu Hadist Riwayat Bukhari dan proses pencarian menggunakan key word tertentu belum tertata dengan rapih sehingga membingungkan pengguna dalam mengakses dan melakukan proses pencarian pada sistem tersebut. 
Proses pencarian menggunakan dua atau lebih dari dua kata dapat dilihat pada Gambar berikut:

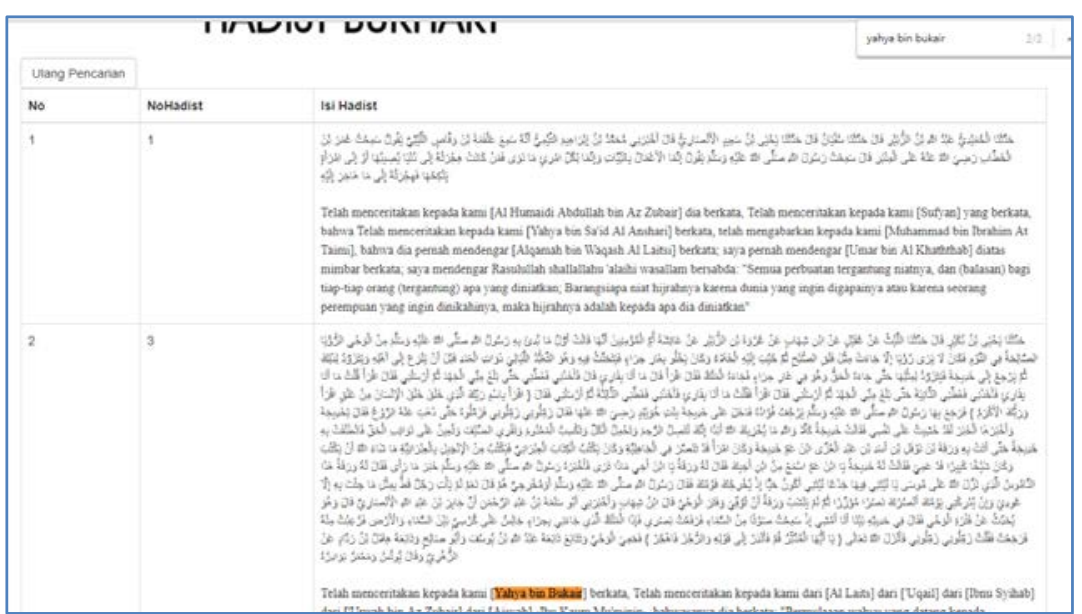

Gambar 1. Pencarian Menggunakan Lebih Dari Dua Kata.

Proses pencarian menggunakan dua atau lebih dari dua kata tidak optimal, hal ini ditujukan pada kata "Yahya bin Bukair" yang dimasukan pada kolom pencarian, namun output yang menampilkan kata "Yahya bin Bukair” tampil pada kolom kedua.

Maka dari itu, hal tersebut mendasari untuk mengangkat penelitian untuk mengoptimalkan proses pencarian pada sistem pencarian kata-kata dalam empat kitab hadis agar dapat membantu pengguna menemukan informasi dari keempat kitab hadis dengan kata kunci tertentu dalam Bahasa Indonesia.

\section{Tinjauan Pustaka}

\subsection{Pendahuluan Terdahulu}

Pengembangan Sistem Pencarian Informasi pada Hadist Riwayat Bukhari pada penelitiannya memaparkan bahwa sistem tersebut berbasis web dan melakukan proses pencarian kitab Hadits Riwayat Bukhari untuk dapat membantu pengguna dalam menemukan hadis dan dapat menemukan informasi nomor dan isi yang lengkap tentang hadist riwayat Bukhari yaitu sebanyak 7008 hadis [3].

Pengembangan Aplikasi Pencarian Hadist Riyadhus Shalihin Imam Nawawi Jilid II Pilihan Berbasis Android dalam penelitiannya melakukan pengembangan aplikasi pencarian hadis yang diambil dari kitab Riyadhus Shalihin Imam Nawawi Jilid II Pilihan berbasis Android. Hadis yang dipilih adalah 100 tema hadis dari kitab tersebut, aplikasi hanya dapat memanggil file yang ditunjuk dan tidak ada input yang dimasukkan ke dalam sistem. Aplikasi tidak memanggil bagian yang ditunjuk menggunakan suara, serta aplikasi tersebut menggunakan citra .jpg untuk menampilkan aksara Arabnya [4].

Dari kedua penelitian tersebut diketahui bahwa keduanya dapat melakukan proses pencarian hadis menggunakan informasi nomor dan isi, namun belum adanya optimasi pencarian dalam mencari informasi menggunakan kata kunci tertentu.

\subsection{Optimasi}

Optimasi yaitu suatu proses untuk mencapai hasil yang ideal atau optimasi (nilai efektif yang dapat dicapai). Optimasi dapat diartikan sebagai suatu bentuk mengoptimalkan sesuatu hal yang sudah ada, ataupun merancang dan membuat sesusatu secara optimal [5]. 


\subsection{Hadis}

Hadis adalah sumber teks penting hukum, tradisi, dan pengajaran dalam dunia Islam. Hadis secara harfiah berarti ucapan atau percakapan,tetapi secara Islam merupakan ucapan dan tindakan yang diwakili oleh Nabi Muhammad Saw [6].

\section{Metode Penelitian}

\subsection{Metode Pengembangan}

Penelitian ini menggunakan metode pengembangan Waterfall, karena metode ini menggambarkan pendekatan yang sistematis dan juga berurutan pada pengembangan perangkat lunak. Metode Waterfall digunakan karena penerapan metode tersebut mudah dan terstrukur. Maksud terstrukur tersebut adalah apabila suatu tahapan terhambat maka tahapan-tahapan selanjutnya tidak dapat dikerjakan secara optimal.

\section{a) Analisis Kebutuhan}

analisis kebutuhan dilakukan unutk menganalisis kebutuhan dan permasalahan pada sistem terdahulu. Pada analisis kebutuhan terdapat dua metode analisis yaitu metode pengumpulan data dan analisis kebutuhan, metode pengumpulan data merupakan metode untuk menganalisis penelitian sebelumnya yang relevan dengan penelitian yang diteliti dan data pendukung untuk pembuatan sistem. Analisis kebutuhan diperoleh bahwa sistem melakukan pencarian informasi hadis lebih optimal, informasi hadis lengkap dan terurut, memudahkan pengguna dalam mendapatkan informasi hadis, dan terdapat emapat kitab.

\section{b) Desain}

Perancangan dimulai dengan menentukan use case diagram, activity diagram, sequence diagram, dan class diagram serta diikuti dengan desain interface. Berikut adalah contoh desain interface halaman utama cari hadis pada sistem optimasi pencarian kata-kata dalam empat kitab hadis, Interface disesuaikan dengan kebutuhan, guna dapat memudahkan dalam menyampaikan informasi yang dibutuhkan. Desain interface halaman utama cari hadis ditunjukkan pada Gambar 2.

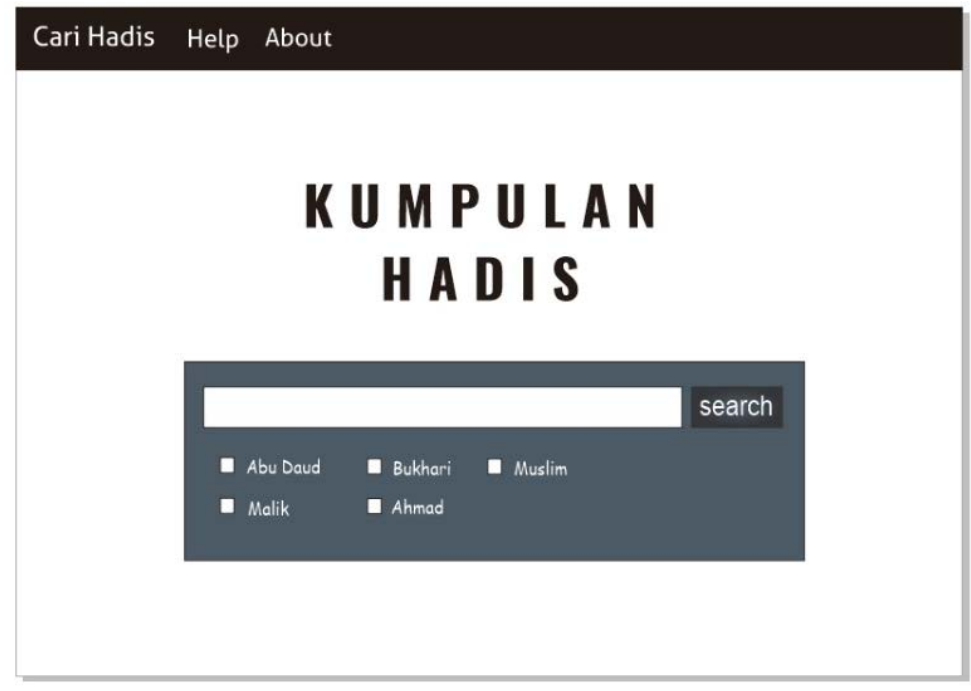

\subsection{Rencana Pengujian}

Gambar 2. Halaman Utama Cari Hadis.

pengujian dilakukan setelah sistem berhasil dibangun, tahapan pengujian perlu dilakukan guna mengetahui sistem yang telah dibangun sesuai dengan yang telah diharapkan atau tidak. Pada pengujian optimasi pencarian kata-kata dalam empat kitab hadis ini 
menggunakan Black Box Testing dan pengujian kuisioner yang akan diambil dari 20 responden.

\section{Hasil Penelitian}

Sistem pencarian kata-kata dalam empat kitab hadis terfokus pada pengoptimalan output pencarian kata-kata dalam kumpulan arti dari empat kitab hadis. Data-data pada sistem pencarian kata-kata dalam empat kitab hadis ini diperoleh atau dikumpulkan dari bot hadits telegram yang kemudian dimasukan pada database menggunakan PhpMyAdmin. Pengembangan implementasi sistem ini menggunakan Framework Laravel dan terdapat tiga menu yaitu Cari Hadis, Help, dan About, Berikut ini adalah layout menu-menu yang ada pada Sistem Pencarian Ka ta-Kata Dalam Kitab Hadis.

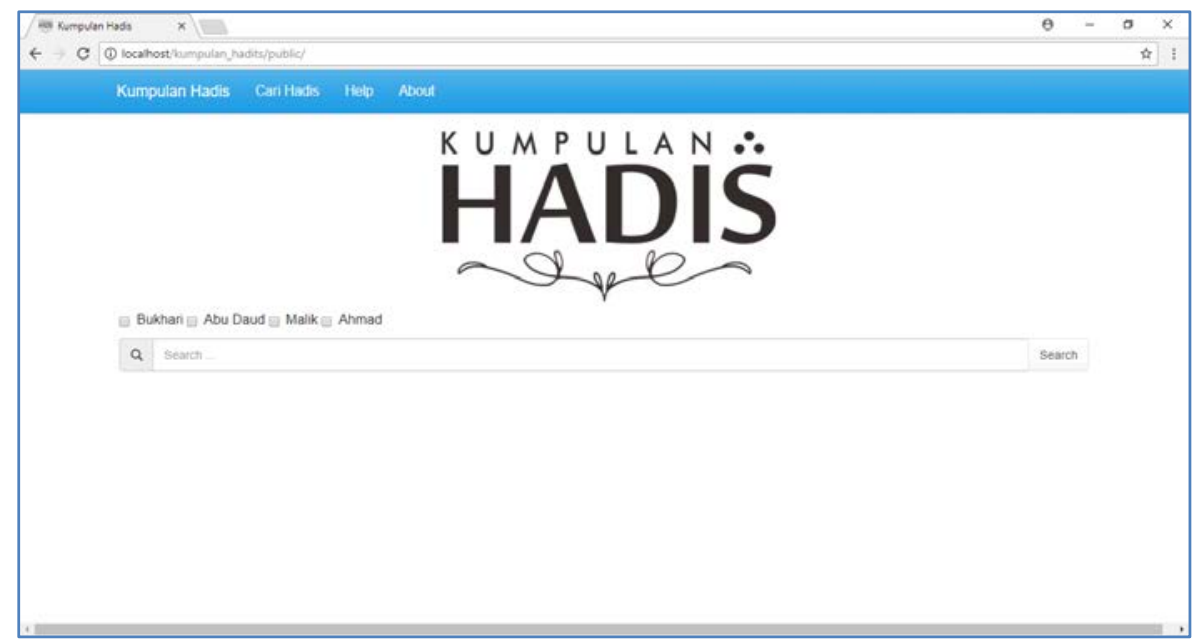

\subsection{Optimasi Sistem}

Gambar 3. Halaman Utama Menu Cari Hadis

Untuk mengetahui optimalitas sistem pencarian kata-kata dalam empat kitab hadis, maka dilakukan proses pencarian 1 kata, 2 kata dan 3 kata pada Sistem Pencarian Kata-Kata Dalam Empat Kitab Hadis dan Sistem Pencarian Informasi Pada Hadits Riwayat Bukhari [3] yang merupakan penelitian sebelumnya yang relevan dengan penelitian yang penulis kembangkan. Kemudian memilih satu hadis yang sama dan dibandingkan letak nomor urutan dan letak layer halaman.

\subsubsection{Pencarian 1 Kata}

Pencarian dengan input 1 kata dilakukan sebanyak tiga kali, yang terdiri dari tiga kata berbeda yaitu: Puasa, Kurma, dan Bersedekah.

Tabel 1. Optimasi Sistem Pencarian dengan 1 Kata

\begin{tabular}{ccccccc} 
& \multicolumn{2}{c}{ Sistem Lama } & \multicolumn{2}{c}{$\begin{array}{c}\text { Sistem Baru } \\
\text { (1 Kitab Hadis) }\end{array}$} & \multicolumn{2}{c}{$\begin{array}{c}\text { Sistem Baru } \\
\text { (4 Kitab Hadis) }\end{array}$} \\
\cline { 2 - 8 } & $\begin{array}{c}\text { Nomor } \\
\text { Urut }\end{array}$ & $\begin{array}{c}\text { Letak } \\
\text { Layer }\end{array}$ & $\begin{array}{c}\text { Nomor } \\
\text { Urut }\end{array}$ & $\begin{array}{c}\text { Letak } \\
\text { Layer }\end{array}$ & $\begin{array}{c}\text { Nomor } \\
\text { Urut }\end{array}$ & $\begin{array}{c}\text { Letak } \\
\text { Layer }\end{array}$ \\
\hline $\begin{array}{c}\text { Puasa } \\
\text { (Hadis Bukhari No. 7) }\end{array}$ & 1 & 1 & 1 & 1 & 1 & 1 \\
\hline $\begin{array}{c}\text { Kurma } \\
\text { (Hadis Bukhari No. 59) }\end{array}$ & 1 & 1 & 1 & 1 & 1 & 1 \\
\hline $\begin{array}{c}\text { Bersedekah } \\
\text { (Hadis Bukhari No. 96) }\end{array}$ & 1 & 1 & 1 & 1 & 1 & 1
\end{tabular}


Dari ketiga proses pencarian dengan input satu kata yang berbeda-beda pada proses yang sama maka dapat disimpulkan belum adanya perbedaan yang cukup berbeda untuk letak dan urutan pada proses pencarian dengan input satu kata. Kemudian dilakukan proses pencarian dengan menggunakan input dua kata yang dilakukan sebanyak tiga kali dengan kata-kata yang berbeda.

\subsubsection{Pencarian 2 Kata}

Proses pencarian menggunakan dua kata dengan input kata-kata yang berbeda sebanyak tiga kali yang terdiri dari kata Unta Merah, Mengadu Domba, dan Puasa Ramadhan.

Tabel 2. Optimasi Sistem Pencarian dengan 2 Kata

\begin{tabular}{ccccccc}
\multirow{2}{*}{ Kata } & \multicolumn{2}{c}{ Sistem Lama } & \multicolumn{2}{c}{$\begin{array}{c}\text { Sistem Baru } \\
\text { (1 Kitab Hadis) }\end{array}$} & \multicolumn{2}{c}{$\begin{array}{c}\text { Sistem Baru } \\
\text { (4 Kitab Hadis) }\end{array}$} \\
\cline { 2 - 7 } & $\begin{array}{c}\text { Nomor } \\
\text { Urut }\end{array}$ & $\begin{array}{c}\text { Letak } \\
\text { Layer }\end{array}$ & $\begin{array}{c}\text { Nomor } \\
\text { Urut }\end{array}$ & $\begin{array}{c}\text { Letak } \\
\text { Layer }\end{array}$ & $\begin{array}{c}\text { Nomor } \\
\text { Urut }\end{array}$ & $\begin{array}{c}\text { Letak } \\
\text { Layer }\end{array}$ \\
\hline $\begin{array}{c}\text { Unta Merah } \\
\text { (Hadis Bukhari No. 3888) }\end{array}$ & 4 & 33 & 4 & 1 & 1 & 1 \\
\hline $\begin{array}{c}\text { Mengadu Domba } \\
\text { (Hadis Bukhari No. 209) }\end{array}$ & 2 & 1 & 1 & 1 & 1 & 1 \\
\hline $\begin{array}{c}\text { Puasa Ramadhan } \\
\text { (Hadis Bukhari No. 1814) }\end{array}$ & 5 & 5 & 2 & 1 & 1 & 1
\end{tabular}

proses pencarian dengan input satu kata yang berbeda-beda pada proses yang sama telah terlihat perbedaan letak keywords yang dimasukan pada kolom pencarian. Kemudian dilakukan proses pencarian dengan menggunakan input tiga kata yang dilakukan sebanyak tiga kali dengan katakata yang berbeda.

\subsubsection{Pencarian 3 Kata}

Pencarian dengan masukan tiga kata merupakan tahap akhir untuk mengetahui optimasi pada sistem berfungsi atau berjalan dengan baik. Hal ini relevan dengan batasan masalah penelitian yaitu Penelitian ini melakukan optimasi pencarian kata-kata pada hadis dengan batasan input-an kata kunci maksimal tiga kata. Serupa dengan proses pencarian yang telah dilakukan sebelumnya, pencarian dengan masukan tiga kata dilakukan sebanyak tiga kali dengan masukan kata-kata yaitu Puasa Bulan Ramadhan, .Selain itu, pencarian dilakukan pada s istem pencarian informasi hadist Bukhari dan dilakukan pada sistem pencarian kata-kata dalam empat kitab hadis dengan memilih kitab Bukhari saja dan memilih keempat kitab.

Tabel 3. Optimasi Sistem Pencarian dengan 3 Kata

\begin{tabular}{ccccccc}
\multirow{2}{*}{ Kata } & \multicolumn{2}{c}{ Sistem Lama } & \multicolumn{2}{c}{$\begin{array}{c}\text { Sistem Baru } \\
\text { (1 Kitab Hadis) }\end{array}$} & \multicolumn{2}{c}{$\begin{array}{c}\text { Sistem Baru } \\
\text { (4 Kitab Hadis) }\end{array}$} \\
\cline { 2 - 7 } & $\begin{array}{c}\text { Nomor } \\
\text { Urut }\end{array}$ & $\begin{array}{c}\text { Letak } \\
\text { Layer }\end{array}$ & $\begin{array}{c}\text { Nomor } \\
\text { Urut }\end{array}$ & $\begin{array}{c}\text { Letak } \\
\text { Layer }\end{array}$ & $\begin{array}{c}\text { Nomor } \\
\text { Urut }\end{array}$ & $\begin{array}{c}\text { Letak } \\
\text { Layer }\end{array}$ \\
\hline $\begin{array}{c}\text { Puasa Bulan Ramadhan } \\
\text { (Hadis Bukhari No. 2581) }\end{array}$ & 10 & 21 & 1 & 1 & 1 & 1 \\
\hline $\begin{array}{c}\text { Hendak Buang Hajat } \\
\text { (Hadis Bukhari No. 4532) }\end{array}$ & 10 & 47 & 1 & 1 & 5 & 1 \\
\hline $\begin{array}{c}\text { Takut Terkena Fitnah } \\
\text { (Hadis Bukhari No. 18) }\end{array}$ & 2 & 1 & 1 & 1 & 1 & 1
\end{tabular}

Setelah melakukan proses pencarian dengan satu kata, dua kata, dan tiga kata serta dilakukan sebanyak masing-masing tiga kali dengan input-an berbeda diperoleh hasil yang berbeda antara kedua sistem. Namun, dalam pencarian dengan memasukan satu kata tidak terlihat perbedaan diantara keduanya baik itu secara letak urutan hadis maupun letak layer hadis. Pada sistem pencarian informasi hadist Bukhari dengan input-an dua dan tiga kata, hadis-hadis yang dicari letaknya masih tidak terurut dan terletak pada halaman yang cukup jauh dari halaman pertama. Sedangkan, pada sistem pencarian kata-kata dalam empat kitab hadis letak hadis yang dicari terletak pada halaman pertama sehingga memudahkan pengguna dalam mendapatkan informasi 
mengenai hadis yang pengguna butuhkan. Sehingga dengan adanya peran lebih memudahkan pengguna dalam mendapatkan informasi dibandingkan dengan sistem sebelumnya, maka sistem yang dikembangkan oleh Penulis sudah cukup optimal dalam melakukan pencarian informasi mengenai hadis.

\subsection{Pengujian}

\subsubsection{Pengujian Black Box}

optimasi pencarian kata-kata dalam empat kitab hadis secara fungsional cukup sesuai dengan spesifikasi. Terdapat skenario pengujian pada sistem yang terkadang masih terjadi error, seperti pada input pencarian dengan satu paragraf masih adanya error yang menyebabkan data tidak tampil secara terurut dan proses pencarian berhenti berjalan. Kemudian pada skenario uji input lebih dari tiga kata kunci terkadang terjadi kesalahan yaitu data menjadi tidak terurut.

Namun, sistem pencarian kata-kata dalam empat kitab hadis masih membutuhkan perbaikan untuk mencapai hasil yang lebih optimal. Pengembangan pada beberapa menu dan fungsi yang belum bekerja dengan baik juga perlu dilakukan untuk lebih memenuhi kebutuhan pengguna.

\subsubsection{Pengujian Kuesioner}

Pengujian Kuesioner melibatkan 20 responden untuk mendapatkan penilaian langsung mengenai sistem yang telah dihasilkan. 20 responden menguji langsung sistem yang telah dibangun dan sistem sebelumnya untuk perbandingan.

a) Kuesioner Pernyataan

Dilakukan perhitungan interval terlebih dahulu sebelum melakukan perhitungan dengan skala likert. Perhitungan dilakukan dengan persamaan sebagai berikut:

$I=\frac{100 \%}{\mathrm{~K}}$

Keterangan:

$I=$ Interval

$K=$ Jumlah Kategori

Dari persamaan tersebut dimasukan data yang sesuai dengan pernyataan yang telah dibuat yaitu sebagai berikut:

$I=\frac{100 \%}{5}=20 \%$

Setelah perhitungan interval telah dilakukan dan didapatkan hasilnya, selanjutnya dibuat rentang skala sehingga dapat diketahui letak rata-rata penilaian responden terhadap setiap poin pernyataan. Jika total skor penilaian responden diperoleh angka 1585, maka penilaian interpretasi reponden terhadap sistem ini adalah hasil nilai yang didapatkan menggunakan rumus index \% sebagai berikut:

Index $\%=\frac{\text { Total Skor }}{\mathrm{Y}} \times 100$

Penyelesaian akhir:

Index $\%=\frac{1585}{1800} \times 100$

Index $\%=88,05 \% \quad$ berada dalam kategori "sangat setuju"

Dari hasil nilai index sebesar 88,05\% maka dapat disimpulkan bahwa responden lebih banyak yang sangat setuju terhadap pernyataan-pernyataan mengenai sistem pencarian kata-kata dalam 4 kitab hadis. 
b) Kuesioner Perbandingan

Berbeda dengan kuesioner pernyataan, untuk mengetahui hasil pengujian pada kuesioner perbandingan hanya dengan membandingkan banyaknya jumlah responden yang memilih diantara kedua sistem. Dari 20 responden yang diberikan 10 pertanyaan setelah dilakukan proses rekapitulasi, data rekapitulasi responden disajikan di lampiran, diketahui bahwa :

Sistem Baru = 190 Jawaban memilih sistem baru.

Sistem Lama $=10$ Jawaban memilih sistem lama.

Sistem Baru > Sistem Lama.

Sehingga dapat disimpulkan bahwa lebih banyak responden yang memilih sistem baru sehingga dapat disimpulkan bahwa sistem baru telah melakukan optimasi cukup baik.

\section{Kesimpulan}

Berdasarkan hasil penelitian yang dilakukan, dapat diambil kesimpulan bahwa pada sistem terdahulu dengan melakukan input-an dua dan tiga kata, hadis-hadis yang dicari letaknya masih tidak terurut dan terletak pada halaman yang cukup jauh dari halaman pertama. Sedangkan, pada sistem yang penulis kembangkan letak hadis yang dicari terletak pada halaman pertama sehingga memudahkan pengguna dalam mendapatkan informasi mengenai hadis yang pengguna butuhkan. Sehingga dengan adanya peran lebih memudahkan pengguna dalam mendapatkan informasi dibandingkan dengan sistem sebelumnya, maka sistem yang dikembangkan oleh Penulis sudah cukup optimal dalam melakukan pencarian informasi mengenai hadis.

\section{Saran}

Dari hasil penelitian yang dilakukan terdapat beberapa rekomendasi sebagai berikut :

1. Untuk pengembangan selanjutnya diharapkan optimasi pencarian dapat lebih kompleks.

2. Dalam pengembangan selanjutnya diharapkan adanya admin sebagai pengelola data hadis agar dapat lebih update.

3. Kitab hadis yang tersedia lebih dari empat kitab hadis.

4. Tampilan sistem dapat dibangun lebih ergonomic.

5. Pada proses pencarian hanya kata-kata yang sama percis saja yang dapat dimasukan, maka dari itu diharapkan adanya pengembangan pada pencarian sistem dapat mencari kata-kata yang hampir sama yang dapat dimasukan.

\section{REFERENSI}

[1] Rasyid, M. Ainur. (2017). Hadits-Hadits Tarbawi. Yogyakarta: Diva Press.

[2] Sanjaya, Ardi. (2016). Optimasi Query Untuk Pencarian Data Menggunakan Penguraian Kalimat. 1.

[3] Sidi, Jaka. (2017). Pengembangan Sistem Pencarian Informasi Pada Hadist Riwayat Bukhari.

[4] Apkuanbo, Harjo. (2015). Pengembangan Aplikasi Pencarian Hadist Riyadhus Shalihin Imam Nawawi Jilid II Pilihan Berbasis Android.

[5] Darmanto, A. (2016). Optimalisasi Sumber Pendapatan Asli Daerah Dalam Pelaksanaan Otonomi Daerah Di Kabupaten Kutai Timur. 18.

[6] Saloot, Mohammad Arshi., Idris, Norisma., Mahmud, Rohana., Ja’afar, Salinah., Thorleuchter, Dirk., dan Gani, Abdullah (2016). "Hadith Data Mining and Classification: A Comparative Analysis.” Artificial Intelligence Review 46(1): 113-28. 